DOI 10.18699/PlantGen2019-019

\title{
Identification of the stem rust resistance genes in the introgression lines of spring bread wheat using molecular markers
}

\author{
Baranova O.A. ${ }^{*}$, Sibikeev S.N. ${ }^{2}$, Druzhin A.E. ${ }^{2}$ \\ ${ }^{1}$ All-Russian Institute of Plant Protection, St. Petersburg, Russia \\ ${ }^{2}$ Agricultural Research Institute of South-East Region, Saratov, Russia \\ *e-mail: baranova_oa@mail.ru
}

A total of the 58 introgression lines and 11 cultivars of spring bread wheat developed by Agricultural Research Institute of South-East Region and cultivated in the Volga Region were analyzed. The lines were obtained with the participation of CIMMYT synthetics, durum wheat cultivars, direct crossing with alien species such as Agropyron elongatum, Ag. intermedium, Aegilops tauschii, different species of the genus Triticum L., Secale cereale and triticale Satu. Cultivars and lines were evaluated for resistance to Lysogorsk and Omsk stem rust pathogen populations (Puccinia graminis f. sp. tritici) and to the Ug99 race group in Kenya (KARI) as well as analyzed for the presence of the known Sr resistance genes (Sr22, Sr25, Sr26, Sr31, Sr35, Sr36, Sr38, Sr39) using molecular markers. The gene $S r 31$ remained effective to the local pathogen population. The 26 wheat lines out of 58 were resistant to all local pathogen populations taken into analysis and the 15 introgression lines were resistant to stem rust in Kenya. The genes $\operatorname{Sr} 31 / \operatorname{Lr} 26$, $\operatorname{Sr} 25 / \operatorname{Lr} 19, \operatorname{Sr} 22, \operatorname{Sr} 35$ and $\operatorname{Sr} 38 / \operatorname{Lr} 37$ were identified in the introgression lines. The gene $S r 31 / L r 26$ was identified in 13 lines. All lines carrying 1RS.1BL translocation (Sr31/Lr26) were resistant to all local pathogen populations taken into analysis. The gene $\mathrm{Sr} 25 / \mathrm{Lr} 19$ was identified in 40 lines. The genes combination $\mathrm{Sr} 31 / \mathrm{Lr} 26+\operatorname{Sr} 25 / \mathrm{Lr} 19$ was identified in 10 lines. The gene $S r 22$ was identified in 2 lines, this fact will be checked in further work, gene $\mathrm{Sr} 35$ - in one line and gene $\mathrm{Sr} 38$ - in two lines. The genes combinations $\operatorname{Sr} 38 / \operatorname{Lr} 37+\operatorname{Sr} 25 / \operatorname{Lr} 19$, Sr35 $+\operatorname{Sr} 25 / \operatorname{Lr} 19$ were identified. The lines with genes combinations $S r 38 / \operatorname{Lr} 37+S r 25 / L r 19$ were resistant to local pathogen populations. The line with gene $S r 22$ was resistant to local pathogen populations and to the Ug99 race group in Kenya. The genes $\mathrm{Sr} 26, \mathrm{Sr} 36$ and $\mathrm{Sr} 39$ were not detected in the analyzed wheat lines. Acknowledgements: Supported by the RFBR No. 18-016-00170a. 